Journal of Business and Tourism

Volume 02 Number 01

January - June, 2016

\title{
EARNINGS VOLATILITY AND CAPITAL STRUCTURE: EMPIRICAL EVIDENCE OF NON-FINANCIAL FIRMS OF PAKISTAN
}

\author{
MUHAMMAD ILYAS \\ Lecturer, Abdul Wali Khan University, Mardan \\ milyas_85@awkum.edu.pk \\ DR. MUHAMMAD JEHANGIR \\ Assistant Professor, Abdul Wali Khan University, Mardan \\ Jehangir@awkum.edu.pk \\ DR. ADNAN AHMAD \\ Assistant Professor, Abdul Wali Khan University, Mardan \\ adnankhattak@awkum.edu.pk
}

\begin{abstract}
In this research investigated capital structure and earning volatility. For this purpose, selected a sample of 267 firms listed on Karachi Stock exchange $e^{I}$ during 2006-2014. Data are panel in nature, therefore used panel data techniques for analysis. Moreover, selected the fixed effect model on the basis of diagnostic tests result. Finally, the results demonstrate that earnings volatility negatively and significantly affect the capital structure of sample firms. Thus, concluded that high volatility reduces the confidence level of creditors.
\end{abstract}

\section{Keywords: Capital Structure, Earnings Volatility, Assets Tangibility, Panel data analysis}

\section{Introduction}

It is generally observed phenomenon that stability of capital market and regulations of the corporate sectors play their role in investment attraction from creditors. However, this is also reported that in various phases in past a number of instable situations are incurred across the globe. Such type of sudden changes and uncertainty shacked the confidence of investors, especially creditors because their confidence on market information is declined. Further, Olakunle (2011) cited that Gregoriou (2010) concluded that due to utmost important role of stock market and listed firms'performance practitioners and academicians are interested to identify the factors responsible for the prices flotations of socks of listed companies. Moreover, reported that they reveal that prices flotations affect the capital structure (CS) of firms. moreover, conclude that price fluctuations attract attention of companies'management, risk arbitrageurs and management of portfolios because prices volatility leads to earnings volatility (EV) and this affect ultimately the CS of firms. moreover, reported that this also affect the expected cash flows of the firms.

This is reported that in the market there are a number of avenues available for firms to financing their assets such as debt, equity and hybrid type of securities. Moreover,

\footnotetext{
${ }^{1}$ Now this is Pakistan Stock Exchange 
management according to their business operations and market conditions avail the appropriate choice of financing. Hence, such decisions increase the level of shareholders'wealth and management is interested in firm value maximization (Olakunle, 2011). Research on CS was created after the initial work of Modigliani and Miller (1958), they established as background of it and assumed a number of assumption that if there is perfect market there will be no influence of CS on the market values of firm. Moreover, they reported that here is no cost of brokerage, no tax, at the same cost available to individual and company financing opportunity and information asymmetric is not exist in the market.

After empirical evidence researchers criticized these assumptions. Therefore, reviewed in 1963 these assumptions and reported that companies take advantages of taxes gain when they financing their assets by debts. This is reported that among a number of indictors of business performance earning is one of the acceptable determinant. Moreover, earnings also show the existing financial position of firms as well the forecasted position (Ovtchinnikov, 2009). This is also reported that the volatility in earnings negatively affect the performance and capital position of firms in firms. Moreover, Ovtchinnikov (2009) reported that "Earning volatility is the fluctuation in the abilityof firm's profitability over time". Hence, due to importance of EV as determinant of CS in this study investigated EV and CS in listed firms of Pakistan.

\section{Literature Review}

Demonstrated that EV positively associated with CS of firms listed in developing economies. They selected a sample of 10 developing economies and concluded that institutional structure in such economies are different (Booth, Aivazian, Demirguc-Kunt, \&Maksimovic, 2001). Similarly, revealed that EV and CS are positively and significantly associated (Burgman, 1996). However, demonstrated that EV and CS are negatively associated in sample firms of developed economies (Bradley, Gregg, Jarrell, \& Kim, 1984). In addition, revealed that in a sample of 81 firms listed on Thailand Stock Exchange during 2004-2008 that CS and EV negatively related (Banchuenvijit, 2011). Further, demonstrated that CS and EV negatively associated in small and medium firms in Australia (Cassar\& Holmes, 2004). Other studies, such as Subadar, Mathew and Wassila (2008) concluded the same findings. They selected a small sample of 15 firms during 1998-2003. Moreover, Ali (2011) demonstrated same findings in a sample of 170 Indian textile companies during 2006-2010. In addition, Sheikh and Zongjun (2011) concluded that EV negatively affect the CS of Pakistani listed firms. however, Ovtchinnikov (2009) find that EV either positively or negatively affect CS because he examined sample firms during regulation and deregulation phases. similarly, Lee and Kwok (1988) examined EV and CS of multinational companies and local listed firms of U.S. results show no significance difference in volatility of these cluster firms. However, Akhtar (2005) concluded that EV is one of the important determinant of CS in MNE's and domestic listed firms. Moreover, Jung and Song (2011) concluded that EV acts as a factor of adjustment of level of debts in the CS of firms.

\section{Hypothesis of the Study}

Pervious empirical studies cannot clearly demonstrate the association of EV and CS, hence the following hypothesis is developed to test in the current study in the context of Pakistan. 
$\mathbf{H}_{\mathbf{0}}$ : Earnings volatility cannot affect capital structure of Pakistani listed firms.

Research Methodology

To investigate EV and CS of firms listed on Pakistan stock market selected a sample of 267 firms. Time period of the study is from 2006-2014 and used for analysis the panel data procedures because the data are panel in nature.

Variables Measurement

Dependent variable of the study is CS and it is calculated such as the ratio of total debts and total assets. Moreover, EV is used as independent variable and it shows theprobability of financial distress and this is reported that it can negatively affect the CS of firms. It is measured as the ratio of EBIT standard deviation and total assets of firms. In addition, in final model included size of firms and assets tangibility as control variables. Size is measured as log of total assets and assets tangibility is the ratio of fixed to total assets of firms.

\section{Model of the study}

CapStrit $_{\text {it }}=\alpha_{0}+\beta_{1}$ EarVola $_{\text {it }}+\beta_{2}$ FS $_{\text {it }}+\beta_{3}$ AssTang $_{\text {it }}+\varepsilon_{\text {it }}$

Here:

CapStr ${ }_{\mathrm{it}}$ is the Capital Structure, EarVola $\mathrm{it}_{\mathrm{it}}$ is Earnings volatility, $\mathrm{FS}_{\mathrm{it}}$ is the size and AssTang $_{i t}$ is assets tangibility of sample firms.

\section{Results}

Table 1 Summary Statistics

\begin{tabular}{ccccc}
\hline & Mean & Std. Dev. & Min & Max \\
\hline CS & 0.47685 & 0.24289 & 0.0139 & 2.866256 \\
EV & -1.1213 & 0.46002 & -3.9954 & 0.8620654 \\
FS & 7.1891 & 1.59367 & -0.5108 & 13.27631 \\
AT & 0.4985 & 0.21648 & 0.00542 & 0.9678799 \\
\hline
\end{tabular}

Table 1 reports the summary statistics, on average firms financing their assets on debts are $47.685 \%$. Moreover, the minimum and maximum values of CS are not having more variation from its mean value. In addition, on average the volatility is negative in Pakistani listed firms and the variation of minimum and maximum values is also reported. Assets tangibility and firm size having low level of deviation from their mean values.

Table 2 Correlation Results

\begin{tabular}{ccccc}
\hline & CS & EV & AT & FS \\
\hline CS & 1.000 & & & \\
& & & & \\
& -0.067 & 1.000 & & \\
& 0.000 & & & \\
AT & -0.105 & -0.292 & 1.000 & 1.000 \\
\hline
\end{tabular}


$0.038 \quad 0.000 \quad 0.000$

Table 2 of the study reports the correlational matrix. The relationship between variables are low and it shows that there are no biased values which can cause the econometric issues in analysis. Moreover, shows that CS and EV are negatively associated. This association is statistically significant and it shows that increase in EV reduces the level of debts in CS of firms. association between variables are highly significant. In addition, AT and FS negatively associated with CS and EV is negatively and positively related with AT and FS respectively. Finally concluded that AT negatively associated with FS.

Table 3 Regression Model and Diagnostic Tests Results of Panel Data Dependent Variable: Capital Structure

\begin{tabular}{ccccc}
\hline & Coef. & Std. Err & T & p-value \\
\hline EV & -0.035 & 0.008 & -4.25 & 0.0000 \\
FS & 0.006 & 0.005 & 1.19 & 0.2330 \\
AT & -0.325 & 0.036 & -8.87 & 0.0000 \\
C & 0.550 & 0.047 & 11.70 & 0.0000 \\
\hline
\end{tabular}

R-square: within $=0.0420$, between $=0.0080$ and overall $=0.0134$

$\mathrm{F}(3,2132)=31.19$ and Prob $>\mathrm{F}=0.0000$

$F$ test: $F(266,2132)=15.99$ Prob $>F=0.0000$

Hausman Test chi2(3) 13.68 and Prob $>$ chi2 $=0.0034$

Table 3 of this study reports the final results. On the basis of diagnostic tests such $\mathrm{F}$ test (Chow test) demonstrated that constant method of panel data is not suitable for analysis. Hence, used test of Hausman to decide between fixed and random models the most appropriate one. The results of this test recommended that suitable model for analysis is fixed effect model and its results are reported in table 3. Results show that EV affect CS negatively and this effect is significant statistically. It reveals that if the level of EV is high then the level of debts in capital structure is low because the level of confidence of creditors are become low. Moreover, FS is positively but insignificantly affect the CS because creditor make investment in all size of businesses. It shows that firms either small or large in size creditor believe that return their investment because of their confidence on capital market standards. Assets tangibility negatively and significantly affect CS. Overall R-square value is 0.01 and F-statistic shows that model is valid for analysis.

\section{Conclusion}

In this paper investigated CS and EV in a sample of 267 listed firms during 2006-2014. Used panel data analysis and revealed that EV affect negatively the level of debts in CS. Moreover, demonstrated that AT affect the level of debts and FS is insignificantly but positively affect CS. Hence, revealed that finally concluded that it is required for management to reduces the level of volatility in their earnings to restore or maintain the sustainable confidence of investors. 


\section{References}

Ali, L. (2011).The determinants of leverage of the listed textile companies in India. European Journal of Business and Management, 3(12), 54-59.

Akhtar, S. (2005). The determinants of capital structure for Australian multinational and domestic corporations. Australian Journal of Management, 30 (2), 321-341.

Booth, L., Aivazian, V., Demirguc-Kunt, A., \&Maksimovic, V. (2001). Capital structures in developing countries. The Journal of Finance, 56(1), 87-130.

Bradley, M., Gregg, A., Jarrell, E., \& Kim, H. (1984). On the existence of an optimal capital structure: Theory and evidence. The Journal of Finance, 39(3), 857-878.

Banchuenvijit, W. (2011). Determinants of capital structure of listed companies in Thailand.

Burgman, T. A. (1996). An empirical examination of multinational corporate capital structure.Journal of International Business Studies, 27(3), 553- 570.

Cassar, G., \& Holmes, S. (2003). Capital structure and financing of SMEs: Australian evidence. Accounting and Finance, 43(2), 123-147.

Jung, B.,\& Song, M. (2011). Earnings volatility and leverage adjustment. 1404- 1436.

Lee, K. \& Kwok, C.C.Y. (1988). Multinational corporations vs. domestic corporations: International environmental factors and determinants of capital

structure.Journal of International Business Studies, 19(2), 195- 217.

Olakunle, A.O. (2011). Examining the impact of stock volatility on capital structure of listed Nigerian firms. Continental J. Social Sciences, 4(1), 3345 .

Ovtchinnikov, A.V. (2009). Capital structure decisions: Evidence from deregulated industries. Journal of Financial Economics, 95(2), 249-274.

Modigliani, F., \& Miller, M. (1958). The cost of capital, corporate finance, and the theory ofinvestment, American Economic Review, 48(4), 261-297.

Modigliani, F., \& Miller, M. H. (1963). Corporate income taxes and the cost of capital:

Acorrection. American Economic Review, 53, 433-492.

Subadar, U. A, Mathew, L., \&Wassila, B. H. (2008). Theories of capital structure:

Evidence from investment and non-investment firms listed on the stock exchange of Mauritius. BAI 2008 International Conference on Business and Information, Korea.

Sheikh, N. A., \&Zongjun, W. (2011). Determinants of capital structure: An empirical study of firms in manufacturingindustry of Pakistan. Managerial

Finance, 37(2), 117-133. 